\title{
Professionalization of the Managerial Capital in the Healthcare Field: a Case of Ukraine
}

\author{
Borshch Viktoriia \\ $\mathrm{PhD}$ in Economics, associate professor \\ Department of Management and innovations Odessa national I. I. Mechnikov University \\ Odessa, Ukraine
}

\begin{abstract}
Main challenges, priorities and trends of the national health care are analyzed in the paper. The general concept of managerial capital was defined; its main sources were analyzed. Objective processes of developing a professional management system have been viewed. Within the framework of the forming organization's management capital the following tasks of healthcare facilities' management were determined. In the paper it is argues, that the process of managerial capital formation is ongoing in the frameworks of managerial staff's professionalization. Thus, the main directions and variants of professionalization of managerial staff in healthcare field are proposed. But nevertheless, it is important to emphasize, that professionalization of managerial staff in Ukrainian health care is very complicated process, due to the lack of special training basis for its realization and, especially, understanding of government its necessity. The problem of forming and developing managers of healthcare facilities has been emphasized in the paper. Requirements for modern healthcare professionals have been identified.
\end{abstract}

Keywords: managerial capital, professionalization, health care, managerial staff, managerial intelligence, healthcare management.

\section{Introduction}

Modern Ukrainian society is characterized by the transformational processes in the economy, activation of political processes, and reformation in the social sphere, an important element of which is the national healthcare system. Today, reforming, and in fact, the creation of a new system of health care, which should occupy a leading position among the main priority areas of state policy, is actual. In our opinion, health policy should be a pivotal element of the state policy and development strategy of the country. Since the individual health and health of the nation are one of the most important criteria for the formation and development of the country's human capital.

Modern indicators of Ukrainian nation's health, namely life expectancy, physical and mental health, mortality and fertility, etc. are threatening. This demonstrates the urgent need for rethinking of the essential principles of social development. That is why understanding the value of human life and health should be the basis of the whole system of social governance, humanistic policy and the transformation of the national health system.

The development of the national economy has a significant impact on the forms and methods of regulation and management of the health sector. On the other hand, the contribution of health care to the economic development of any country is also evident. The volume of medical services provided to the population and expressed in value form has a positive impact on GDP. More resources are used in the production of medical services, higher are the qualifications of medical personnel and greater are the size of national income created by the industry. Medical staff is a provider of medical services and, thus, they prevent illness and treating patients, thereby improving the socio-demographic situation and increasing the country's labor potential. 


\section{Theoretical Framework of the Study}

The conceptual framework of the study was based on the theory of human and intellectual capital. Problem of the professionalization of the managerial capital is the urgent one, but in the theoretical frameworks it has not been still researched significantly. Such Ukrainian and foreign scientists, as R. Ancoff, I. Ansoff, M. Armstrong, P. Drucker, E. A. Kuznietsov, B. Milner have researched the methodological basis and innovative forms of the professional management system. But this problem has not been researched in the context of the healthcare system.

\section{The Purpose of the Study}

The main goal of this research is to analyze the methodological basis of the process of managerial staff's professionalization in the healthcare sphere.

\section{Research Questions}

The following research questions were addressed in the study:

1. Why is it so important to form the basis for managerial staff's professionalization in Ukrainian healthcare field?

2. What is the process of managerial staff's professionalization?

\section{Results / Discussions}

\section{State of the national healthcare system and health management}

National healthcare system and healthcare management, which were formed before the mid-1990s of the 20th century, focused on the extensive way and methods of development. Criteria for evaluating the effectiveness of functioning both the whole healthcare system and individual economic entities were based not on indicators of quality of treatment, prevention and diagnostic services, but first of all, on quantitative parameters of normative provision and health protection facilities.

Besides, the residual type of funding the social sphere in general, and in particular the health sector, has led to a deterioration of the state of population health. For the development of the national healthcare system in those years, no more than $3.3 \%$ of GDP was allocated, while in economically developed countries, funding for this industry was directed from 8 to $14 \%$ of GDP. In addition, the administrative-command health management system existed in a planned economy was focused on tight hierarchical vertical (subordinate) relationships and compulsory motivation to work. Horizontal (coordination) and feedback in the health management system were virtually absent. However, the theory and practice of management shows that without this type of communication (firstly, the reverse one) it is impossible to ensure the stability and efficiency of functioning any complex management system, more socio-economic one, in which it is difficult to formalize all resources flows and information links between system's elements.

From the management theory of complex systems, it is known that the feedback mechanism allows implementing in practice dynamic methods for assessing the system's effectiveness and monitoring the mode to compare the achieved results of medical care and the community resources' costs. Finally, the lack of feedback mechanisms has led to the alienation of the general public from participation in solving many social issues, including the one related to the environment and the population's health.

The reasons prevented the effective healthcare sector's development in a planned economy were the inputbased financing of this sphere, based on state budget funds, the lack of necessary motivation and incentives for medical and administrative staff at all levels regarding the use of advanced world experience etc. Ultimately, all these factors together with the external factors of organizing the country's economic system have caused the need for the transition of the national health system to market methods and modern management theory and practice.

Improving the managerial processes in the national healthcare sector has been yet carried out due to economic experiments, which allowed obtaining a certain socio-economic effect through the use of financial and economic mechanisms. But it is a main mistake of Ukrainian government. The economic components of the old public healthcare system with total state ownership do not take into account managerial approaches. The introduction of new progressive methods, techniques and management technologies faces the difficulties caused by the specifics of medical activity: 
1) the sphere of public health is non-productive, when the process of providing and receiving services coincides in time and space; consequently, there is a problem in accounting for the contribution of health care to the growth of country's national wealth;

2) the labour subject in this field is a person, hence there are "subjective-subjective" relations;

3 ) the medical service is a "living labour", which complicates the definition of its cost, and hence the profit of the healthcare institution;

4) the subject to appropriation in the healthcare field is a specific labor activity of medical personnel;

5) effectiveness of the healthcare institutions and healthcare management is much more complicated, than in the industrial field, because of the necessity to analyze apart from the economic efficiency, social and medical one;

6) managerial staff in Ukrainian health care is formed spontaneously, without the existence of specific knowledge and education in the sphere of management, economic, financial and marketing.

Thus, the task of the modern stage of health sector's development is to create such a development strategy and adjust it so that this branch can balance the interests of the population, state and healthcare institutions. In this regard, it is necessary to focus on the formation and development of managerial capital of this branch.

\section{Managerial capital}

In recent years, special attention has been paid to the scientific management category, such as "managerial capital". This term is still not definitively defined.

So in Law of Ukraine On changes in legislation of Ukraine to improve legislation regarding the healthcare institutions activity, it is argued that a certain dominant force that forms a higher level of human and intellectual capital, is precisely the managerial capital. We understand that managerial capital is an effective management activity that creates an innovative format for the intellectual capital's active formation.

Hence, managerial capital is a "meta-capital" of any organization that is represented by an adequate quality of its management system.

Moreover, management capital, according to our opinion, is derived from human capital. However, it does not cover all the productive forces of the organization, but only includes a narrow category of human resources, whose activities are aimed at creating and operating an optimal management system of the enterprise (group of enterprises).

The concept of managerial capital is based on the understanding that managerial knowledge, competences and professional experience have to result the profit and to develop and use mechanisms for its extended reproduction using innovative social factors and economic growth.

Consequently, taking into account that managerial capital is a specific manifestation of human capital, we can determine its basic features: (1) it is inseparable from the leader; (2) its formation and development is impossible without additional efforts of the individual; (3) can be realized only through the work of its carrier and the creation of a company's quality management system; (4) provides organization with an increase in profits by increasing productivity, efficiency and effectiveness of management organization, that is, it is one of the factors enhancing the organization's economic security (Borshch, 2019).

That is, the problem of the use and reproduction of managerial capital is not possible only at the individual, organizational, national or international level - it must be solved in a complex, providing a new quality of the management system as a whole.

The main sources of management capital are presented in Fig. 1. 


\begin{tabular}{|l|l|}
\hline \multicolumn{1}{c|}{} & Vocational training of the managerial staff \\
\hline Science \\
\hline Education \\
\hline Instruction \\
\hline \multirow{2}{*}{$\begin{array}{c}\text { Managerial } \\
\text { capital }\end{array}$} & Business environment \\
\hline \multirow{2}{*}{ Security } \\
\hline Professional knowledge \\
\hline Professional associations \\
\hline Culture and art \\
\hline Health care \\
\hline Information environment \\
\hline Civil society and economic freedom \\
\hline
\end{tabular}

Fig. 1. Key sources of managerial capital formation

Source: (Kuznietsov, 2017).

The problem of forming managerial capital takes on its basis the development of an organization's professional management system. Only a well-formed professional management system in an organization can be a guarantor of the fact that, under the implementation of other conditions (i.e., the availability of managerial intelligence, managerial professional competence and experience, which are ensured by a continuous process of management professionalization, Fig. 2), it will generate managerial capital.

Objective processes of developing a professional management system in the organization and forming the managerial capital allow us to form the thesis that management activity is a highly intelligent system of a management team's activity headed by a highly effective leader.

Thus, within the framework of the forming organization's management capital the following tasks should be determined:

1) forming a qualitative system of organization's professional management;

2) forming an effective management team;

3) providing leadership and team-building processes, searching for a "golden" ratio of leadership with the organizational structure of management;

4) ensuring an effective process of functional training and professionalization of management personnel;

5) provision of innovative training and development of innovative thinking of organization's all personnel;

6) ensuring the continuous development of the personnel as a guarantee for increasing the effectiveness of its activities;

7) forming a qualitative system of making a management decision as the main "product" of management activities (Borshch, 2013).

According to Kuznietsov, 2017, managerial capital is a professional and intellectual system of interaction between members of the management team in order to solve the problem, or a set of problems of socioeconomic development of small and large organizational structures, which have basic resources, a system of priority goals and understandable mechanisms sustainable social and economic growth.

We consider managerial capital in the system of management professionalization (Fig. 2). 
Mechanism of management professionalization

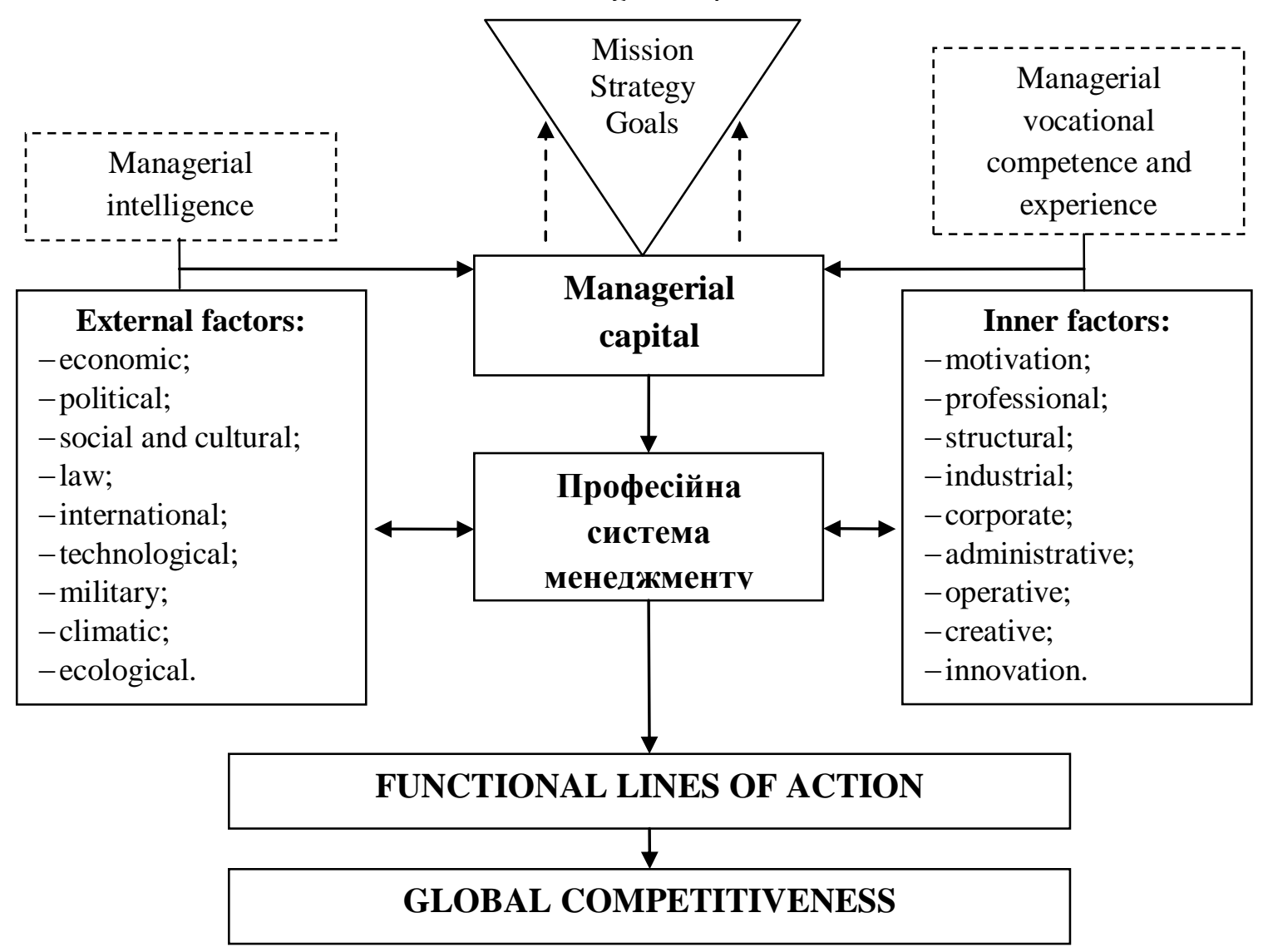

Fig. 2. Managerial capital in the professionalization mechanism

Source: (Kuznietsov, 2017).

From Fig. 2, we see that forming the organization's managerial capital is influenced by two groups of factors: external and internal ones. In this case, the important elements that form the managerial capital are the mechanism of management professionalization, managerial intelligence and managerial professional competence and experience.

The professionalization of management activity, in general terms, is defined as the formation of an individual as a professional manager, from the moment he has elected profession, until the moment of retirement.

\section{Professionalization of managerial staff in health care}

In the context of the national health system's reformation, when the issues of healthcare management are topical, the modern labor market in the health sector needs management specialists. Legally, such a need was defined in the framework of the implementation of the healthcare institutions' autonomization principle, which is guided by the Law of Ukraine On changes in legislation of Ukraine to improve legislation regarding the healthcare institutions activity, and on the basis of implementing market economy mechanism in the national health system. Thus, there is a need for the formation of proper medical management, which, in turn, requires the availability of a qualitatively new specialist in management, such as healthcare manager whose activities, unlike the chief physician of the healthcare institution (whose main function is the organization of the medical process) aims to ensure the quality, effective and efficient operation of the whole healthcare facility.

The problem of forming such a specialist is interdisciplinary, since it requires special training in the field of management and medicine. Consequently, the modern challenges of the of management professionalization process are the following:

- dynamically growing knowledge in the field of management and related sciences (such as finance, marketing, etc.), as well as medicine; 
- multidisciplinary training;

- complicated decision-making processes;

- rapid growth of related health professionals;

- intensification of international mobility;

- the need to develop cognitive knowledge and soft skills in health care professionals;

- tendency to reduce costs both in the educational process and in the provision of medical care.

Consequently, the main task of the professionalization process is to build a process of training specialists in the field of healthcare management taking into account the above-mentioned challenges.

Such a process can be provided in two ways:

I. The first one is the situation, when the basic education is aimed at obtaining a diploma in medicine or pharmacy, and a master's degree in management or public health management.

II. The second one is the situation, when professionalization begins immediately with a diploma specialist in the field of management or public administration in the health sector.

The first variant is widespread in Ukraine, since there is still practice from the Soviet era, when senior management positions were occupied by medical professionals who grew up on a career ladder, but they did not receive any special education in management.

Today, the second option is still not popular, as the problem of management professionalization in the healthcare system is not relevant to modern society, since it is a leveled understanding that the management of a healthcare institution has a specialist in the management field rather than a specialist in the medical sector, which has got promotion to chair the healthcare institution.

Current changes in the national healthcare system and the existing international practice in medicine and management, dictate new requirements for a modern healthcare professional. He must have two main components:

1) practical intelligence (which is basic for assumption of office), which is formed on the basis of knowledge, practical skills and competencies in the field of management, economics, marketing, financial management, human resources management, management research, etc.;

2) emotional intelligence, which consists of cognitive and psycho-emotional components.

As a whole, the practical and emotional intelligence are the "executive intelligence", under which we understand the system of intellectual or cognitive abilities as prerequisites for managerial success. At the core of this is the provision that the absolute majority of situations in the management of any organization imply the need to develop three main types of managers' competencies: problem solving; interaction with people; managing yourself.

\section{Conclusion}

Consequently, the modern labor market places more and more high and specific demands on potential employees, these requirements become more specific for each professional group and the main requirement is the deepening or specialization of knowledge and skills. The labor market of medical workers is no exception and we tend to distribute the therapeutic (clinical) function and its organization and management by the healthcare institution itself. Such specialization is aimed at increasing the efficiency of the medical institution, finding new ways to improve its activities, financial and managerial autonomy.

Thus, the task of training of highly skilled specialists in the field of management of healthcare institutions becomes a problem for modern higher education institutions.

\section{References}

[1] Borshch V. I. (2013). Upravlencheskii kapital kak osobaia forma chelovecheskogo kapitala [Managerial capital as the form of human capital]. Zb. materialiv mizhnar. nauk.-prakt. konf. "Ekonomichna polityka derzhavy $v$ umovakh transformatsiinykh zmin". - Economical policy of the state in the conditions of transformational changes: Collection of the proceedings of the international scientific and practical conference. 1. (2): 55-57.

[2] Borshch V. I. (2019). Kontseptsiia upravlinskoho kapitalu v suchasnii systemi upravlinnia okhoronoiu zdorov'ia Ukrainy [The concept of manageria capital in the modern health care management system of Ukraine]. Mechanisms and strategies of development of economic entities in the context of integration processes: materials of a scientific and practical INTERNET 
conference of students and young scientists with international participation Przeworsk, 19 February 2019. 58-59.

[3] Zakon Ukrainy Pro vnesennia zmin do deiakykh zakonodavchykh aktiv Ukrainy shchodo udoskonalennia zakonodavstva z pytan diialnosti zakladiv okhorony zdorovia vid 06.04.2017 № 2002-VIII [Law of Ukraine on 06.04.2017 № 2002-VIII On changes in legislation of Ukraine to improve legislation regarding the healthcare institutions activity]. https://zakon.rada.gov.ua/laws/show/2002-19

[4] Kuznietsov E. A. (2017). Metodolohiia profesionalizatsii upravlinskoi diialnosti v Ukraini. Monohrafiia [Methodology of professionalization of managerial activity in Ukraine. Monograph]. Kherson. 